\title{
PENERAPAN NILAI-NILAI MORAL DAN KARAKTER DALAM PPKn DI SMP DARUL HIKMAH MATARAM
}

\author{
Azhar ${ }^{1}$, Achmad Djunaidi² \\ ${ }^{1}$ Pendidikan Pancasila dan Kewarganegaraan, Universitas Muhammadiyah Mataram, azhar45@gmail.com \\ ${ }^{2}$ Pendidikan Pancasila dan Kewarganegaraan, Universitas Muhammadiyah Mataram, djuanidiachmad@gmail.com
}

\begin{tabular}{l} 
INFO ARTIKEL \\
\hline Riwayat Artikel: \\
Diterima: $\quad$ 12-Februari- \\
2018 \\
Disetujui: 12-Maret-2018 \\
\hline
\end{tabular}

Kata Kunci:

Nilai Moral

Karakter

\section{A. LATAR BELAKANG}

Pendidikan adalah usaha sadar untuk menyiapkan peserta didik melalui kegiatan bimbingan, pengajaran, dan atau latihan bagi peranannya dimasa yang akan datang. Dalam hal ini sekolah sebagai suatu lembaga pendidikan formal yang secara sistematis merencanakan bermacam-macam lingkungan, yakni lingkungan pendidikan yang menyiadakan berbagai kesempatan bagi peserta didik untuk melakukan berbagai kegiatan

\begin{abstract}
Abstrak: Nilai-nilai moral dan karakter di Indonesia masih sangat memprihatinkan terutama dalam dunia pendidikan maraknya terjadi tindakan kekerasan dan perbuatan asusila seperti, pemerkosaan, tawuran antar pelajar, pelecehan seksual dan lain sebagainya. Tujuan penelitian adalah untuk menjelaskan penerapan nilai-nilai moral dan karakter dalam pembelajaran PPKn di SMP Darul Hikmah Mataram, dan mengidentifikasi faktor yang mempengaruhi moral dan karakter siswa di SMP Darul Hikmah Mataram. Metode penelitian yang digunakan adalah penelitian kualitatif dengan pendekatan deskriptif, pengumpulan digunakan adalah observasi, wawancara, dan dokumentasi. Subyek penelitian adalah, guru PPKn, guru BK, siswa SMP, serta kepala sekolah. Analisis data menggunakan model interaktif. Hasil penelitian ini menunjukkan bahwa penerapan nilai-nilai moral dan karakter dalam pembelajaran Pendidikan Pancasila dan Kewarganegaraan dibutuhkan kesiapan mempersiapkan perangkat pembelajaran yang lengkap, nilai-nilai moral dan karakter siswa perlu diajarkan. Nilai-nilai moral dan karakter yang ajarkan yaitu mengamalkan nilai-nilai pancasila, juga diajarkan karakter sikap toleransi, menghargai, berbicara sopan santun, kejujuran, dan saling menghargai dan tolong menolong untuk diajarkan kepada peserta didik tersebut. Faktor yang mempengaruhi nilai-nilai moral dan karakter siswa dilihat dari segi positif seperti, mengajarkan hal-hal bernuansa agama, merubah peserta didik menjadi lebih baik, patuh dan taat. Segi negatif seperti, factor lingkungan, factor teman sepergaulan, dan factor teknologi.
\end{abstract}

\begin{abstract}
Moral and character values in Indonesia are still very alarming especially in the world of education where there are widespread acts of violence and immoral acts such as rape, brawls between students, sexual harassment and so on. The purpose of the study was to explain the application of moral and character values in PPKn learning at Darul Hikmah Middle School in Mataram, and identify factors that influence the morale and character of students in Darul Hikmah Middle School in Mataram. The research method used is qualitative research with a descriptive approach, the collection used is observation, interviews, and documentation. The research subjects were PPKn teachers, BK teachers, middle school students, and school principals. Data analysis using interactive models. The results of this study indicate that the application of moral values and character in the learning of Pancasila and Citizenship Education requires readiness to prepare a complete learning device, moral values and character of students need to be taught. Moral values and characters that teach are practicing the values of the Pancasila, also taught the character of tolerance, respect, speaking of manners, honesty, and mutual respect and helping help to be taught to these students. Factors that influence students' moral and character values are seen in a positive way, such as teaching religious nuances, changing students to be better, obedient and obedient. Negative aspects such as environmental factors, peer factors, and technological factors.
\end{abstract}

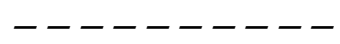

belajar. Maka dari itu setiap kegiatan pendidikan diarahkan kepada tercapainya pribadi-pribadi yang berkembang secara optimal sesuai potensi masingmasing peserta didik. Sebagai suatu proses psikologis, pendidikan tidak dapat dipisahkan dari kegiatan belajar mengajar. Dengan demikian pendidikan adalah proses interaksi peserta didik yang memiliki tujuan tertentu. Salah satu tujuan pendidikan adalah mempersiapkan peserta didik agar dapat mempermainkan perannya 
dalam berbagai lingkungan hidup secara tetap untuk masa yang akan datang.

Sebagai bangsa yang bijak harus berfikir cerdas untuk jangka panjang, kedepannya yang memegang negara ini adalah anak-anak muda sebagai generasi penerus bangsa, oleh karena itu harus memperbaiki dan menyiapkan generasi penerus bangsa yang diharapkan mempu bangkit, membangun dan mengembangkan bangsa demi mencapai segala cita-cita luhur bangsa. Sehingga anak harus memiliki nilai-nilai moral dan karakter yang utama.

Kondisi ini masih jauhnya dari bangsa Indonesia dari cita-cita yang dituju terlihat dari merosotnya moral dan karakter yang dimiliki anak bangsa. Permasalahan moral dan karakter anak bangsa menjadi permasalahan yang sangat mendasar dinegeri ini. Kualitas etika dan moral yang semakin rendah dari kondisi yang kecil hingga ke kondisi yang besar mengakibatkan terhambatnya kemajuan bangsa Indonesia dalam waktu yang cukup lama. Permasalahan moral dan karakter yang rendah ini sangat banyak terjadi pada anak-anak yang seharusnya masih dalam perkembangan dan pertumbuhannya diisi dengan hal-hal positif sehingga melahirkan generasi penerus bangsa yang beradab dan mempunyai moralitas dan karakter yang baik.

Keberadaan guru bagi suatu bangsa amatlah penting, apalagi bagi suatu bangsa yang sedang membangun, terlebih-lebih lagi bagi keberlangsungan hidup bangsa ditengah-tengah lintasan perjalanan jaman dengan teknologi yang kian canggih dan segala perubahan serta pergeseran nilai yang cenderung memberi nuansa kepada kehidupan yang menuntut ilmu dan seni dalam kadar dinamik untuk dapat mengadaptasikan diri.

Permasalahan moral dan karakter tersebut diharuskan adanya tindakan-tindakan untuk mengatasinya, jawaban yang paling kuat yaitu melalui pendidikan. Pendidikan melalui orang tua, guru, dan lingkungan sekitar. Dengan mengaktualisasikan nilainilai pancasila dan spiritual keagamaan pada siswa diharapkan dapat mengembangkan moral dan karakter untuk mewujudkan generasi-generasi yang dapat membawa bangsa kedepannya lebih baik.

Hasil observasi pada SMP Darul Hikmah Mataram bahwa nilai-nilai moral dan karakter dikalangan siswa sengatlah rendah seperti dekadensi etika, sopan santun ketidak jujuran, membolos, menyontek dan lain-lain, berkurangnya rasa hormat terhadap orang tua dan guru sudah menjadi masalah yang saat ini belum dapat diatasi secara tuntas.

Hal inilah yang harus diperbaiki dan dibenahi oleh seseorang yang ada di SMP Darul Hikmah Mataram untuk memberikan contoh teladan yang baiktentang dampak dari kenakalan remaja, dan memberikan bimbinganyang tepatguna yang dapat dijadikan filter atau penyaring oleh siswa untuk mengontrol diri dari adanya pengaruh-pengaruh negatif dalam kehidupan sehari-hari.
Selain itu kekuatan moral dan karakter peserta didik menjaga adab mereka menghadapi keboborokan moral dan karakter yang sering terjadi. Dengan meningkatkan moral dan etika diharapkan siswa tidak hanya berfikir dengan benar tetapi juga bertindak dengan benar dan membentuk karakter yang kuat. Pengembangan nilai moral untuk peserta didik ini bisa dilakukan dalam tri pusat pendidikan yang ada, yaitu keluarga, sekolah,dan masyarakat.

Didalam dunia pendidikan sejumlah mata pelajaran dapat membentuk karakter bangsa, salah satu diantaranya adalah mata pelajaranPendidikan Pancasila dan Kewarganegaraan (PPKn). Pendidikan Pancasila dan Kewarganegaraan (PPKn) merupakan mata pelajaran yang sarat isi dengan nilai-nilai Pancasila untuk membentuk kepribadian. Pendidikan Pancasila dan Kewarganegaraan (PPKn) tidak cukup hanya sampai pada penghafalan, melainkan PPKn diterapkan dalam kehidupan sehari-haripeserta didik dalam bentuk perbuatan, nilai-nilai yang terkandung dalam Pancasila bukan untuk dihafal melainkan untuk dipraktekan dalam kehidupan nyata. Oleh karena itu pembelajaranPendidikan Pancasila dan Kewarganegaraan(PPKn) perlu mengutamakan perilaku.

Dalam hidup berbangsa dan bernegara dewasa ini Pendidikan Pancasila dan Kewarganegaraan (PPKn) sangatlah penting dalam mewujudkan pribadi bangsa yang berkualitas. Dan Pendidikan Pancasila dan Kewarganegaraan(PPKn) haruslah mampu menumbuhkan kemandirian sehingga peserta didik dapat tumbuh sebagai manusia yang berkualitas dalam kehidupan berbangsa dan bernegara.

Pendidikan moral dan karakter merupakan salah satu wujud penanaman nilai-nilai moral dan karakter kepada warga sekolah yang meliputi kompenen pengetahuan dan kesadaran atau kemauan, dan tindakan untuk melaksanakan nilai-nilai tersebut. Melihat permasalahan di atas pengembangan moral dan karakter sangat dibutuhkan dalam pendidikan saat ini. Selain itu guru sangat berpengaruh dalam pembentukan dan pengembangan moral dan karakter peserta didik.

Tujuan yang ingin dicapai dalam penelitian ini adalah untuk mengetahui pengembangan nilai-nilai moral dan karaktersiswa dalam pembelajaran PPKn di SMP Darul Hikmah Mataram dan untuk mengetahui faktor yang mempengaruhi nilai-nilai moral dan karakter siswa di SMP Darul Hikmah Mataram.

\section{B. METODE PENELITIAN}

1. Jenis Penelitian yang Digunakan

Penelitian ini termasuk penelitian kualitatif, penelitian kualittaif adalah metode penelitian yang berlandaskan pada filsafat postpositivisme, digunakana untuk meneliti pada kondisi obyek yang alamiah, (sebagai lawannya adalah eksperimen) dimana peneliti adalah sebagai instrumen kunci, pengambilan sampel sumber data dilakukan secara purposive dan snowbaal, 
tehnik pengumpulan dengan trianggulasi (gabungan), analisis data bersifat induktif/kualitatif, dan hasil penelitian kualitatif lebih menekankan makna dari pada generalisasi[1].

Pendekatan yang digunakan adalah pendekatan deskriptif berupaya untuk menjelaskan dan mencoba mendeskriptif dan mempelajari pengembangan nilainilai moral dan karakter bangsa dalam pembelajaran Pendidikan Kewarganengaraan (PKn) di SMP Darul Hikmah Mataram.

\section{Lokasi Penelitian}

Penelitian ini akan dilaksanakan di Kelurahan Karang Genteng Mataram Nusa Tenggara Barat 2017/2018 tepatnya di SMP Darul Hikmah Mataram.

3. SubjekPenelitian

Dalam penelitian kualitatif tidak menggunakan istilah populasi, tetapi Spradley dinamakan social situation atau situasi sosial yang terdiri dari tiga elemen yaitu: tempat, pelaku, dan aktivitas yang berinteraksi secara sinergis.

Karena penelitian kualitatif berangkat dari kasus tertentu yang ada pada situasi sosial tertentu dan hasil kajiannya tidak akan diberlakukan kepopulasi tetapi ditransferkan ke tempat lain pada situasi sosial pada kasus yang dipelajari. Sampel dalam penelitian kualitatif bukan dinamakan responden, tetapi narasumber atau partisipan, informan, teman dan masyarakat dalam penelitian[2].

Dalam penelitian kualitatif tekhnik sampling yang digunakan adalah purposive sampling dan snowballsampling. Purposive sampling adalah tekhnik pengambilan sampel sumber data dengan pertimbangan tertentu. Snowballsampling adalah tekhnik pengambilan sampel sumber data yang pada awalnya jumlahnya sedikit lama-lama menjadi besar[1].

Berdasarkan hal tersebut di atas bahwa, penentuan tekhnik sampel dalam penelitian menggunakan tekhnik purposive sampling, jika data yang diperoleh tekhnik ini masih kurang maka akan digunakan snowballsampling. Digunakan tekhnik purposive sampling ini karena informasi ini dianggap lebih tahu dan paham terhadap masalah yang diteliti dan dapat memberikan data yang lebih lengkap,mereka itu adalah kepala sekolah, guru PPKn, guru BK dan siswa pada umumnya. Sedangkan tekhnik snowball sampling ini digunakan karena data yang diperoleh dari informan sebelumnya dirasakan belum sempurna atau masih kurang untuk itu dilakukan penambahan terhadap informan agar data yang diambil sesuai dengan target dan harapan dalam pelaksanaan penelitian yaitu sampai data jenuh (Maksudnya kalau data sudah tidak bisa digali lagi atau jawaban responden akhirnya hanya berputar ke itu-itu saja)

4. Metode Pengumpulan Data

a. Teknik Wawancara

Wawancara merupakan pertemuan dua orang untuk bertukar informasi dan ide melalui tanya jawab, sehingga dapat dikonstruksikan makna dalam suatu topik tertentu[3]. Wawancara digunakan sebagai tehnik pengumpulan data apabila peneliti ingin melakukan studi pendahuluan untuk menemukan permasalahan yang harus diteliti, tetapi juga apabila peneliti ingin mengetahui hal-hal dari responden yang lebih mendalam. Tehnik pengumpulan data ini mendasarkan diri pada laporan tentang diri sendiri atau self-report, atau setidak-tidaknya pada pengetahuan atau keyakinan pribadi[4].

Peneliti memilih tekhnik wawancara dalam penelitian ini untuk mengetahui sejauh mana pengembangan nilai-nilai moral dan karakter dalam pembelajaran Pendidikan Kewarganegaraan (PKn) di SMP Darul Hikmah Mataram. Sesuai dengan subjek peneltian bahwa wawancara dilakukan dilakukan kepada 2 subjek yaitu guru dan siswa. Untuk memperoleh data yang real, peneliti melakukan wawancara dengan sspontan atau tidak terpimpin namun masih memperhatikan fokus penelitian yang diteliti. Peneliti melontarkan beberapa pertanyaan kepada guru dan siswa, tentang bagaiman mengembangkan nilai-nilai moral dan karakter dalam pembel;ajaran pendidikan kewarganegaraan (PKN)? dan pertanyaan-pertanyaan yang lain.

\section{b. Teknik Observasi}

observasi adalah dasar semua ilmu pengetahuan. Para ilmuwan hanya dapat bekerja berdasarkan data, yaitu fakta mengenai dunia kenyataan yang diperoleh melalui observasi[4]. Data itu dikumpulkan dan sering dengan bantuan berbagai alat yang sangat canggih, sehingga benda-benda yang sangat kecil (proton dan elektron) maupun yang sangat jauh (benda ruang angkasa) dapat diobservasi dengan jelas.

mengobservasi adalah satu proses yang komplek, suatu propses yang tersusun dari berbagai proses biologis dan psikologis[5]. Semua bentuk penerimaan data dilakukan dengan cara merekam kejadian menghitungnya, mengukurnya, dan mencatatnya. Sedangkan pengumpulan data dengan observasi langsung atau dengan pengamatan langsung adalah merupakan cara pengambilan data dengan menggunakan mata tanpa ada pertolongan alat standar lain untuk keperluan peneliti[6]. Observasi menjadi observasi berpartisipasi (participan observation), observasi yang secara terang-terangan dan tersamar (ovet observation dan cover observation), dan observasi yang tak berstruktur (unstruktur observation)[1].

Dalam penelitian ini peniliti menggunakan jenis observasi partisipatif yaitu dalam observasi ini peneliti terlibat dengan kegiatan sehari-sehari orang yang sedang diamati atau yang digunakan sebagai sumber data penelitian. Sambil melakukan pengamatan, peneliti ikut melakukan apa yang dikerjakan oleh sumber data, dan ikut merasakan suka dukanya.

c. Tekhnik Dokumentasi

Dokumentasi merupakan catatan peristiwa yang sudah berlalu. Dokumentasi bisa berbentuk tulisan, 
gambar, atau karya-karya monumental dari seseorang. Dokumentasi yang berbentuk tulisan misalnya catatan harian, sejarah kehidupan (life histories), ceritera, biografi, peraturan, kebijakan. Dokumentasi yang berbentuk gambar, misalnya foto, gambar hidup, sketsa dan lain-lain. Dokumentasi yang berbentuk karya misalnya karya seni, yang dapat berupa gambar, patung, film, dan lain-lain. Studi dokumentasi merupakan pelengkap dari penggunaan metode observasi dan wawancara dalam penelitian kualitatif.

Hasil penelitian dari observasi dan wawancara, akan lebih kredibel/dapat dipercaya kalau didukung oleh sejarah pribadi kehidupan dimasa kecil, di sekolah, di tempat kerja, di masyarakat dan autobiografi. Tetapi perlu dicermati bahwa tidak semua dokumentasi memiliki kredibelitas yang tinggi. Sebagai contoh banyak foto yang tidak mencerminkan keadaan aslinya, karena foto dibuat untuk kepentingan tertentu. Demikian juga autobiografi yang ditulis untuk dirinya sendiri, sering cenderung subyektif[1].

\section{Jenis dan Sumber Data}

Jenis data dalam pelaksanaan penelitian dapat dibagi menjadi 2 bagian pokok yakni jenis data kualitatif dan data kuantitatif yakni jenis data yang berbentuk kata, kalimat, skema, dan gambar. Sedangkan jenis data kuantitatif adalah data yang berupa angka-angka atau bilangan sesuai dengan bentuknya. Adapun jenis data yang digunakan dalam penelitian ini adalah data kualitatif bukan data kuantitatif, karena tidak berhubungan dengan angka-angka (statistik), namun dijelaskan dengan kata-kata atauu kalimat.

Bila dilihat dari sumber datanya, maka pengumpulan data dapat menggunakan sumber primer dan sumber sekunder. Sumber primer adalah sumber data yang langsung memberikan data pada pengumpulan data, sedangkan sumber sekunder merupakan sumber yang tidak langsung memberikan data kepada pengumpulan data, misalnya lewat orang lain atau dokumen[1].

Sumber data primer dari penelitian ini adalah wawancara laangsung yang dilakukan peneliti dengan responden atau guru dan siswa di SMP Darul Hikmah Mataram dari hasil observasi awal yang dilakukan. Sedangkan untuk data sekunder diperoleh dari pencatatan dokumen yang ada di SMP Darul Hikmah Mataram maupun informasi yang berhubungan dengan nilai moral dan karakter.

6. Teknik Analisis Data

Data adalah proses mencari dan menyusun secara sistematis data yang diperoleh dari hasil wawancara, catatan lapangan, dan dokumentasi dengan cara mengorganisasikan data kedalam suatu kategori, menjabarkan kedalam unit-unit, melakukan sintesis, menyusun kedalam pola, memilih mana yang penting dan akan dipelajari, dan membuat kesimpulan sehingga mudah dipahami oleh diri sendiri maupun orang lain[7].
Ada tiga (3) tahapan dalam menganalisis data kualitatif yaitu:

a. Reduksi Data

Merupakan

proses

pemilihan

data,pemusatan,perhatian,pengabstrakan,dan

transformasi data kasar yang muncul dari catatancatatan tertulis dilapangan. Data yang direduksi adalah tentang pengembangan nilai-nilai moral dan karakter dalam pembelajaran PPKnyang diperoleh berdasarkan wawancara dan observasi[1].

b. Penyajian Data

Merupakan sekumpulan informasi tersusun yang memberikan kemungkinan adanya penarikan kesimpulan. Setelah data direduksi maka data tersebut disajikan secara deskriptif, dimana hasil wawancara yang telah dilakukan diubah bahasanya menjadi kalimat baku sehingga mudah dimengerti dan dipahami.

c. Menarik Kesimpulan

Menarik kesimpulan atau vertifikasi data dalam rangka memuat kesimpulan hasil penelitian yang dituang dalam pembahasan. Setelah data direduksi dan disajikan maka dilakukan kesimpulan tentang pengembangan nilai-nilai moral dan karakter dalam pembelajaran pendidikan kewarganegaraan.

\section{HASIL DAN PEMBAHASAN}

\section{Penerapan Nilai-nilai Moral dan Karakter dalam Pembelajaran Pendidikan Pancasila dan Kewarganegaraan di SMP Darul Hikmah Mataram}

PPKn sebagai Pendidikan moral dan karakter merupakan salah satu misi yang harus diemban. Misi lain adalah sebagai pendidikan politik/pendidikan demokrasi, pendidikan hukum, pendidikan HAM dan bahkan sebagai pendidikan anti korupsi, dibandingkan dengan mata pelajaran lain, mata pelajaran PPKn dengan agama memiliki posisi sebagai ujung tombak dalam pendidikan moral dan karakter. Maksudnya dalam kedua mata pelajaran itu, pendidikan moral dan karakter harus menjadi tujuan pembelajaran. Perubahan moral dan karakter peserta didik merupakan usaha yang disengaja atau direncanakan bukan sekedar dampak atau pengiring.

Hal ini dapat ditunjukan bahwa komponen PPKn adalah pengetahuan, keterampilan, moral dan karakter kewarganegaraan. Dengan kata lain tanpa adanya kebijakan pengintegrasian, pendidikan moral dan karakter kedalam berbagai mata pelajaran, PPKn harus mengembangkan pendidikan moral dan karakter. Lebihlebih dengan adanya kebijakan pengembangan pendidikan moral dan karakter yang terintegrasi, maka hal ini merupakan tantangan untuk menunjukan bahwa PPKn sebagai ujung tombak yang tajam bukan tumpul bagi pendidikan moral dan karakter.

Sementara fungsi dari PPKn itu sendiri adalah sebagai wahana untuk membentuk warga negara yang cerdas, terampil, bermoral dan berkarakter yang setia kepada bangsa dan negara Indonesia, dengan merefleksikan dirinya dalam kebiasaan berpikiran, bertindak sesuai dengan amanat Pancasila dan UUD 1945. Pembelajaran PPKn sangat penting diberikan kepada peserta didik 
dikarenakan Indonesia masih cenderung rendah dalam hal moral dan karakter, khususnya di dalam lingkungan sekolah sehingga tidak terjadi hal-hal yang tidak diinginkan seperti, kekerasan, pembunuhan, pemerkosaan, tawuran antara pelajar dan lain sebagainya. Namun semua hal diatas sedikit demi sedikit mulai teratasi, karena guru PPKn dan mata pelajaran Pendidikan Pancasila dan Kewarganegaraan mampu memberikan teladan yang baik.

Guru PPKn harus mempersiapkan apa yang menjadi bahan ajaran dalam proses belajar mengajar khusnya dalam pembelajaran PPKn untuk menerapkan moral dan karakter peserta didik yang baik untuk masa yang akan datang seperti halnya:

a. Guru mempersiapkan Perangkat Pembelajaran

Guru adalah sebagai pendidik untuk regenerasi bangsa, maka dari itu sebelum melakukan pembelajaran di kelas, guru terlebih dahulu mempersiapkan perangkat pembelajaran mulai dari mempersiapkan silabus dan RPP. Serta menggunakan metode pembelajaran dan penilian sikap yang tercantum dalam kurikulum 2013. Dalam proses pembelajaran guru memberikan motivasi dan juga ceramah berkaitan dengan materi pelajaran, guru memberikan latihan serta tugas. Karena media pembelajaran siswa telah mereka sediakan sendiri seperti LKS dan lainnya.

b. Mata Pelajaran Pengetahuan Agama Islam

Ada istilah yang senantiasa diajarkan ketika seseorang membicarakan tentang etika sosial manusia. Dan diantara istilah itu adalah moral dan karakter. Seperti yang dijelaskan diatas, bahwa pengertian dari moral dipakai untuk merujuk kepada ssesuatu tindakan atau perbuatan yang sesuai dengan ide-ide umum yang berlaku dalam suatu komunitas atau lingkungan tertentu. Konsep moral dan karakter dalam islam bertujuan untuk membangun ahlak yang lebih baik dalam diri manusia karena dalam Islam menyarankan agar memberikan latihan moral dan karakter ini dimulai sejak usia dini.

c. Memberikan Contoh Perilaku Teladan

Guru dalam proses pendidikan di sekolah sangat berperan penting, karena guru sebagai pendidik, pembimbing dan pengajar, pembina dan menjadi suri tauladan khusunya guru PPKn itu sendiri, akan senantiasa memberikan contoh tingkah laku yang baik yang diharapkan dalam berbagai interaksi, baik dengan siswa, sesama guru, maupun dengan para staf yang lain. Dalam penerapan nilai-nilai moral dan karakter dalam pembelajaran PPKn bahwa guru sangat penting dalam menerapkan moral dan karakter, dalam penerapan moral dan krakter itu sendiri cukup baik, terlihat dari beberapa kesiapan yang dimiliki oleh guru dalam menyiapkan bahan ajaran dalam proses belajar mengajar, mulai dari tidak datang terlambat saat jam ngajar, memakai pakaian yang rapi dan dengan menggunakan bahasa yang sopan dan mudah dipahami oleh siswa. Hal tersebut merupakan usaha guru untuk menerapkan nilai-nilai moral dan karakter siswa di SMP Darul Hikmah Mataram.

d. Menerapkan pembelajaran berbasis nilai moral dan karakter.

Peran guru PPKn sangatlah penting, selain mendidik guru PPKn adalah untuk membentuk siswa agar menjadi manusia yang cakap dan bersusila, berguna bagi agama bangsa dan negara. Karena siswa adalah regenerasi bangsa dimasa yang akan datang. Pengembangan pembelajaran PPKn di sekolah harus memprioritaskan kualitas intelektual dan kualitas moral dan karakter yang mengarah pada pembentukan ahlak, sifat, watak dan kepribadian. Dengan pendidikan moral dan karakter yang diterapkan secara sistematis dan berkelanjutan, seorang anak akan menjadi cerdas emosinya. Kecerdasan emosi ini adalah bekal penting dalam mempersiapkan anak atau siswa menyongsong masa depan, karena seorang anak akan lebih mudah dan berhasil menghadapi segala macam tantangan kehidupan, termasuk tantangan untuk berhasil secara akademis.

e. Memberikan pehamaman tentang moral dan karakter dalam pembelajaran Pendidikan Pancasila dan Kewarganegaraan, bahwa tujuan dari PPKn itu sendiri ialah agar peserta didik memiliki kemampuan sebagai berikut:

1) Berpikir kritis, rasional, dan kreatif dalam menanggapi isu kewarganegaraan.

2) Berpartisipasi secara aktif dan bertanggung jawab, dan bertindak secara cerdas dalam berperilaku moral, karakter, sikap dan teladan yang baik dalam masyarakat agar dapat hidup bersama di dalam lingkungan masyarakat dan bangsa lainnya.

3) Berinteraksi dengan baik bersama teman sepergaulan dan tidak hanya kepada teman sepergaulan saja, akan tetapi berinteraksi dengan bangsa-bangsa lain dalam percaturan dunia secara langsung atau tidak langsung dengan memanfaatkan teknologi informasi dan komunikasi.

\section{Nilai-nilai Moral dan Karakter Siswa di SMP Darul Hikmah Mataram}

Moral atau dalam kata lain disebut kesusilaan adalah keseluruhan norma yang mengatur tingkah laku manusia di masyarakat ataupun lingkungan sekolah untuk melaksanakan perbuatan-perbuatan yang baik dan benar[8]. Jadi pendidikan moral ditunjukan untuk memagari manusia dari, melakukan perbuatanyang buruk yang tidak sesuai dengan norma-norma yang ada, baik itu dalam lingkungan masyarakat, lingkungan sekolah, berbangsa dan bernegara.

Dalam kurun satu dekade ini, bangsa Indonesia mengalami kemunduran moral dan karakter yang sangat hebat, ditandai dengan tingginya freesex dan seks bebas dikalangan remaja, maraknya penggunaan obat-obatan terlarang, sering terjadinya bentrokan antara pelajar maupun bentrokan di lingkungan masyarakat. Pendidikan moral dan karakter adalah kunci untuk perbaikan sosial dan kemajuan peradaban bangsa yang menjunjung tinggi integritas nilai dan kemanusiaan. Harapan dari pendidikan moral dan karakter adalah tercapainya kesimbangan antara pengetahuan dan moral. Dilihat dari sekolah SMP Darul Hikmah Mataram bahwa penerapan nilai-nilai moral dan karaktrer diketahui secara umum sudah baik, namun selama melakukan penelitian, diperoleh data terkait nilai-nilai moral dan karakter siswa, ada yang positif dan ada yang negatif.

Berdasarkan hasil penelitian yang dilakukan oleh peneliti dengan melakukan observasi dan wawancara yang peneliti lakukan, didapatkan hasil sebagai berikut:

Nilai- nilai moral dan karakter dari segi positif[9]:

a. Mengajarkan tentang hal-hal yang bernuansa agama seperti, sholat duha berjama'ah, imtaq, sholawat dan 
bagi yang mondok atau tidak mondok dianjurkan untuk melakukan sholat magrib, isya subuh dan ngaji berjama'ah dan memberikan arahan tentang alkitab diniyah.

b. Merubah peserta didik menjadi lebih baik dan bijak, karena menjadikan manusia cerdas dan pintar, boleh jadi mudah melakukannya, tetapi menjadikan manusia agar menjadi orang yang baik dan bijak, jauh lebih sulit atau bahkan sangat sulit.

c. Agar menjadi peserta didik yang bertanggung jawab terhadap dirinya, bangsa dan Negara.

d. Harus patuh, taat dan hormat kepada semua guru di sekolah SMP Darul Hikmah Mataram.

e. Adanya rasa saling menghormati antara teman, yang kecil menghormati yang lebih besar, yang besar menyayangi yang kecil.

f. Peserta didik harus mengenal segala peraturan yang dibuat oleh yayasan karena dibawah naungan yayasan.

g. Memebrikan pendidikan agama di sekolah seperti, menerapkan pembelajaran aqidah ahlak dan pagi harinya memberikan arahan yang bersifat membangun untuk meningkatkan nilai moral dan siswa.

h. Sikap disiplin ditunjukan peseta didik di SMP Darul Hikmah Mataram pada saat datang ke sekolah sebelum bel berbunyi, siswa langsung bersalaman dengan guru yang ada disekitar gerbang tersebut.

i. Saling menghargai dan tolong menolong antara siswa dan guru, jika ada guru dan teman yang mengalami kesulitan maka siswa wajib menolongnya.

j. Adanya penggunaan bahasa yang baik, sopan dan santun dalam berkomunikasi dengan guru maupun sesama siswa.

Nilai-nilai Moral dan Karakter[10] dari segi Negatif :

1) Lingkungan keluarga

Keluarga sebagai lingkungan pertama yang mempengaruhi perkembangan nilai moral dan karakter seseorang. Biasanya tingkah laku seseorang berasal dari bawaan ajaran orang tuanya, orangorang yang tidak memiliki hubungan yang harmonis dengan orang tuanya di masa kecil, kemungkinan besar mereka tidak mampu mengembangkan super egonya sehingga mereka biasa menjadi orang yang sering melakukan pelanggaran norma.

2) Lingkungan sekolah

Di sekolah, anak-anak mempelajari nilai-nilai moral, karakter dan norma yang berlaku di masyarakat sehingga mereka juga dapat menentukan mana tindakan yang baik dan boleh dilakukan. Tentunya dengan bimbingan guru.

3) Faktor teman sepergaulan

Teman sebaya merupakan faktor yang sangat berpengaruh terhadap kehidupan pada masa-masa remaja. Karena remaja dalam masyarakat khsusnya disekolah seperti sekarang ini menghabiskan sebagian besar waktunya bersama teman sebaya mereka.

Teman sepergaulan sangatlah berperan penting, peranan teman-teman pergaulannya terhadap remaja terutama berkaitan dengan moral, karakter, sikap, minat, penampilan, perilaku. Remaja seringkali menilai bahwa dirinya memakai model pemakaian yang sama dengan anggota kelompoknya yang populer maka, kesempatan baginya untuk diterima oleh teman sepergaulannya.
4) Faktor perubahan sosial

Faktor perubahan sosial ini sangat berpengaruh terhadap lembaga-lembaga, khsusnya dalam lembaga pendidikan dan lingkungan masyarakat yang mempengaruhi sistim sosialnya adalah, nilai, moral, karakter, sikap-sikap sosial dan pola perilaku, diantara kelompok-kelompok dalam lingkungan sekolah maupun lingkungan masyarakat.

5) Faktor teknologi

Pengaruh kecanggihan teknologi juga memiliki pengaruh kuat terhadap terwujudnya suatu nilai. Di era sekarang, remaja atau peserta didik banyak menggunakan teknologi untuk belajar maupun hiburan. Contoh seperti, internet memiliki fasilitas yang menawarkan berbagai informasi yang dapat diakses secara langsung.

Nilai positifnya, ketika remaja atau siswa mencari bahan pelajaran yang mereka butuhkan mereka dapat mengaksesnya dari internet. Namun internet juga memiliki nilai negative seperti tersedianya situs porno yang dapat merusak moral dan karakter remaja.

\section{SIMPULAN DAN SARAN}

Hasil penelitian menunjukkan bahwa penguatan nilai moral dan karakter bangsa dapat dilakukan dengan cara memberikan ilmu pengetahuan, dan mengutamakan moral, karakter, sikap, etika dan tingkah laku sesuai dengan pancasila dan Undang-undang dasar 1945.

Faktor yang mempengaruhi moral dan karakter siswa yaitu, segi positif dan segi negatif. Nilai positif terdiri atas: a) mengajarkan tentang hal-hal yang bernuansa agama seperti, sholat duha berjama'ah, imtaq, sholawat dan bagi yang mondok atau tidak mondok di anjurkan untuk melakukan sholat magrib, isya subuh dan ngaji berjama'ah dan memberikan arahan tentang alkitab diniyah. b) agar menjadi peserta didik yang bertanggung jawab terhadap dirinya, bangsa dan Negara. c) harus patuh, taat dan hormat kepada semua guru di sekolah SMP Darul Hikmah Mataram. d) adanya rasa saling menghormati antara teman, yang kecil menghormati yang lebih besar, yang besar menyayangi yang kecil. Sementara bernilai negatif terdiri atas faktor lingkungan, faktor teman pergaulan, faktor perubahan sosial dan faktor HP atau teknologi, budaya yang tidak etis.

Dengan demikian disarankan, bagi kepala sekolah, untuk meningkatkan program-program sekolah yang berkaitan dengan nilai-nilai moral dan karakter. Guru, lebih memperhatikan pendidikan anak, pendidikan yang tidak hanya mencerdaskan otak atau IQ semata dan juga proses belajar mengajar dalam hal materi saja, akan tetapi selalu menerapkan nilai-nilai moral dan karakter agar peserta didik mempunyai budi pekerti yang baik untuk generasi bangsa, karena melihat situasi dan kondisi Indonesia saat ini. Siswa, dapat menjalani proses belajar mengajar dengan baik, giat dan tekun dalam belajar, sehingga dapat mencapai hasil yang diharapkan oleh guru, orang tua dan keluarga. Serta dapat meningkatkan nilai-nilai moral dan karakter di lingkungan sekolah, lingkungan masyarakat, keluarga 
dan teman pergaulan, tetap mengikuti dan meningkatkan peraturan yang bernuansa agama di sekolah misalnya: 1) Sholat duha berjama'ah, sholat dzuhur berjama'ah, 2) imtaq dan yasinan, 3) sopan, santun, dan selalu patuh dan taat terhadap guru, 4) tidak melakukan anarkis dan tawuran antara pelajar, 5) tidak freesex dan seks bebas. Peneliti selanjutnya, dapat mengkaji lebih lanjut mengenai nilai-nilai moral dan karakter siswa di SMP Darul Hikmah Mataram.

\section{UCAPAN TERIMA KASIH}

Penulis mengucapkan terima kasih kepada editor yang senantiasa memberikan saran dan masukan kepada penulis sehingga artikel ilimiah ini selesai dengan baik.

\section{DAFTAR RUJUKAN}

[1] P. Sugiyono, Metode Penelitian Kuantitatif, Kualitatif, dan $R \& D .2013$.

[2] P. Sugiyono, "Dr. 2010," Metod. Penelit. Kuantitatif, Kualitatif, dan R\&D. Bandung CV Alf.

[3] K. G. Esterberg, "Qualitative methods in social research," 2002.

[4] A. Sugiyono, "Pengantar Statistik Pendidikan," Jakarta Graf. Persada, 2004.

[5] S. Hadi, "Metodologi research jilid I," Yogyakarta Andi, vol. 94, p. 95, 2004.

[6] S. Nasution, Berbagai pendekatan dalam proses belajar dan mengajar. PT. Bina Aksara, 2000.

[7] B. A. S. Afifuddin and B. A. Saebani, "Metodologi penelitian kualitatif," Bandung CV Pustaka Setia, 2009.

[8] H. Gunawan, "Pendidikan Karakter," Bandung Alf., 2012.

[9] M. F. Hidayatullah and M. Rohmadi, Pendidikan karakter: membangun peradaban bangsa. Yuma Pustaka, 2010.

[10] M. Mustari and M. T. Rahman, "Nilai karakter: refleksi untuk pendidikan karakter." Laksbang Pressindo, 2011. 